\title{
PENGEMBANGAN MEDIA PEMBELAJARAN PERMAINAN ULAR TANGGA UNTUK MENINGKATKAN MOTIVASI BELAJAR SISWA DAN HASIL BELAJAR IPS DI SEKOLAH DASAR
}

\author{
Rifki Afandi \\ FKIP Universitas Muhammadiyah Sidoarjo \\ Surel:wanyiect@yahoo.com
}

\begin{abstract}
Abstrak
Penelitian ini bertujuan mengembangkan media pembelajaran permainan ular tangga dalam pembelajaran ilmu pengetahuan sosial (IPS) di sekolah dasar untuk meningkatkan motivasi belajar dan hasil belajar siswa. Salah satu permasalahan pendidikan adalah minimnya sarana dan prasarana, sehingga guru dituntut kreatif dalam meningkatkan kualitas pembelajaran dikelas, seperti mengembangkan media pembelajaran. Salah satu media pembelajaran yang menarik dan mengatasi kebosanan siswa dalam kegiatan pembelajaran yaitu kegiatan pembelajaran berbasis permainan, seperti penerapan media pembelajaran permainan ular tangga. Penelitian ini mengembangkan media pembelajaran permainan ular tangga dalam pembelajaran ilmu pengetahuan sosial (IPS) di sekolah dasar. Pengembangan penelitian mengadobsi model 4D dari model Thiagarajan, dkk . yaitu define, design, develop, dan dissaminate. Teknik pengumpulan data dalam penelitian melalui observasi, pemberian angket, dan tes. implementasi media pembelajaran permainan ular tangga dilaksanankan uji coba dua, uji coba penelitian dilaksanakan di SDI Yapita Surabaya. Hasil implementasi media pembelajaran permainan ular tangga motivasi belajar siswa meningkat $66,7 \%$ pada aspek keaktifan belajar dan semangat belajar, sedangkan aspek ketertarikan motivasi belajar siswa meningkat $70 \%$. Sedangkan hasil belajar siswa mengalami peningkatan $40 \%$ dari $55 \%$ siswa yang mencapai nilai dibawah KKM (kriteria ketuntasan minimun) menjadi $100 \%$ semua siswa mencapai nilai diatas KKM (kriteria ketuntasan minimum).
\end{abstract}

Kata Kunci: Media Pembelajaran, Motivasi Belajar dan Hasil Belajar

\begin{abstract}
This research is aimed to develop snakes and ladders game as instructional media on the social science subject in elementary school to improve learning motivation and learning achievement for the students. One of the problems in education is the lack of educational facilities and infrastructure, so teachers are required to be creative in improving the quality of learning in class, such as by developing the learning media. One of the interesting learning medium that can overcome the boredom of students in learning activities is gamebased learning activities, such as the implementation of snakes and ladders as an instructional media. This study developed snakes and ladders game in the learning process on social science subject in elementary school. This study adopted Thiagarajan et al. 4D model consist of define, design, develop, and dissaminate. The data is collected through observation, questionnaires, and test. The implementation of snakes and ladders game as learning media is conducted in Islamic Elementary School (SDI) Yapita Surabaya. The findings showed that the students' motivation increased from the value of $66,7 \%$ on the aspect of active learning and learning enthusiasm, while the aspect of interest in students' motivation increased to the value of $70 \%$. Moreover, the result of students learning outcome
\end{abstract}


increased by $40 \%$ from $55 \%$ of students who reached a value below the minimum passing criteria to $100 \%$. As a result, all students achieved score above the minimum passing criteria.

Keywords: Learning Media, Learning Motivation and Learning Achievement.

\section{PENDAHULUAN}

Belajar merupakan suatu proses kegiatan memperoleh informasi dari berbagai sumber, atau kegiatan yang dilakukan untuk mempelajari suatu hal agar mencapai tujuan yang di inginkan dari pengalam yang di peroleh, sehingga terjadi perubahan prilaku. Kegiatan belajar dapat dilakukan dimana pun, asalakan pebelajar tersebut merasa nyaman dan mendukung dalam kegiatan belajar. Namun, kegiatan belajar secara formal dilaksanankan di sekolah, dimana sekolah tempat pertemuan guru dan peserta didik dalam kegiatan pembelajaran.

Sekolah merupakan salah satu lembaga pendidikan formal untuk mencapai tujuan pendidikan nasional. Sebagai mana tercantum dalam undang-undang sistem pendidikan nasional No. 20 Tahun 2003 menyatakan tujuan "pendidikan nasional yaitu untuk mengembangkan potensi peserta didik agar menjadi manusia yang beriman dan bertakwa kepada Tuhan Yang Maha Esa, berakhlak mulia, sehat berilmu, cakap, kreatif, mandiri dan menjadi warga negara yang demokratis serta bertanggung jawab” (Depdiknas, 2003).

Ilmu Pengetahuan Sosial (IPS) adalah bidang studi yang mempelajari, menelaah dan menganalisis gejala dan masalah sosial di masyarakat ditinjau dari berbagai aspek kehidupan secara terpadu (Sapriya, Istianti, \& Zulkifli, 2007:5). Sedangkan Barr (1978:18) dalam Winataputra, dkk. (2007) menyatakan "social studies is an integration of social sciences and humanities for the purposes of intruction in citizenship education. Berdasarkan pendapat tersebut IPS merupakan suatu bidang studi yang menganalisis permasalahan sosial di masyarakat yang didalamnya terintegrasi dari ilmu sosial dan ilmu humaniora untuk tujuan pendidikan.

IPS bertujuan "membina anak didik menjadi warga negara yang baik, memiliki keterampilan dan kepedulian sosial bagi dirinya, masyarakat dan negara" (Sumaatmadja, 2007). Sedangkan National Council for The Social Studie dalam Winataputra, dkk. (2007) tujuan ilmu pengetahuan sosial salah satunya adalah civic responsibility and active civic participation. Berdasarkan pendapat tersebut bidang studi IPS bertujuan untuk mendidik peserta didik agar menjadi warga negara yang baik, memiliki keterampilan sosial, berakhlak mulia dan bertanggung jawab pada diri sendiri dan negara.

Sekolah Dasar Islam Yapita merupakan sekolah dasar terletak di kota Surabaya, hasil observasi dan wawancara dengan guru kelas III di SDI Yapita Surabaya bahwa siswa kurang tertarik dan merasa bosan untuk belajar mata pelajaran IPS, sehingga kurang siswa memahami isi materi mata pelajaran IPS, dalam artian motivasi belajar dan hasil belajar siswa kurang pada IPS, di kelas III guru belum perna mencoba mengembangkan media pembelajaran permainan ular tangga. Di SD Yapita Surabaya memakai dua kurikulum, untuk kelas III dan Kelas VI Memakai kurikulum KTSP 2006 dan unruk kelas I, II, IV dan V memakai kurikulum 2013.

Menurut Sardiman (1986) dalam Zubaidah (2008:25) motivasi belajar merupakan faktor psikis yang bersifat non intelektual dan peranannya yang sangat khas yaitu menumbuhkan gairah, merasa 
senang dan semangat belajar. Motivasi belajar merupakan salah satu unsur penunjang keberhasilan pembelajaran. Motivasi belajar adalah suatu kekuatan dalam diri seseorang yang timbul dalam kegiatan belajar memiliki rasa ketertertarik, aktif, dan semangat dalam belajar.

Pemahaman siswa terhadap isi materi yang diajarkan merupakan hasil belajar kognitif yaitu salah satu tujuan pembelajaran yang di capai, hasil belajar adalah hasil ketercapain yang diperoleh siswa dalam kegiatan pembelajara sesuai dengan ktiteria acuan tujuan pembelajaran yang ditetapkan. Salah satu indikator hasil belajar yang baik, dimana siswa mampu memahami isi materi yang diajarkan oleh guru.

Pelaksanaan pendidikan tentunya tidak mudah dalam mencapai tujuan pendidikan nasional, permasalahan pendidikan di Indonesia begitu kompleks, salah satu permasalahan yaitu siswa kurang termotivasi dalam belajar, hal tersebut sesuai pernyataan Alma, dkk. (2010:11) "pembelajaran ilmu pengetahuan sosial merupakan pembelajaran yang sangat membosankan".

Menurut Winingsih, dkk (2007) salah satu permasalahan pendidikan di Indonesia yaitu sarana dan prasarana belum mendukung proses belajar mengajar, dalam artian sarana dan prasarana sekolah di Indonesia belum memadai. Undang-undang sisdiknas No. 20 Tahun 2003 pasal 45 menyatakan setiap satuan pendidikan formal dan non formal menyediakan sarana dan prasarana yang memenuhi keperluan pendidikan (Depdiknas, 2005).

Pernyataan tersebut menyatakan bahwa setiap satuan pendidikan wajib menyediakan sarana dan prasarana segala sesuatu yang berhubungan dengan kegiatan belajar mengajar di kelas seperti media pembelajaran. Namun, penyediaan kebutuhan kegiatan belajar mengajar seperti media pembelajaran tidaklah muda, karena harga media pembelajaran cukup mahal bagi sekolah tertentu, dalam artian tidak semua sekolah mampu untuk menyediakan media pembelajaran dalam mendukung kegiatan belajar mengajar. Permasalah tersebut tentunya menuntut guru untuk kreatif dalam proses kegiatan belajar mengajar, sehingga proses kegiatann belajar mengajar tetap berjalan dengan baik.

Sesuai undang-undang No. 14 Tahun 2005 tentang guru dan dosen bahwa "guru harus memiliki kompetensi pedagogik", dimana guru harus mampu menguasai proses pembelajaran, dalam artian guru menguasai strategi pembelajaran dan mampu membuat media pembelajaran yang inovatif sesuai kebutuhkan dalam proses kegiatan pembelajaran di kelas.

Kreatifitas guru dituntut ketika kondisi sekolah minim dengan sarana dan prasarana, salah satu kreatifitas guru yaitu dengan menyediakan media pembelajaran, guru harus mampu membuat media pembelajaran yang inovatif untuk mendukung proses pembelajaran. Menurut Arsyad (20011:12) media pembelajaran adalah sebuah alat yang berfungsi untuk menyampaikan pesan pembelajaran, Skiner dalam Sadiman, dkk. (1984:9) menyatakan salah satu komponen penting dalam kegiatan belajar mengajar adalah media pembelajaran.

Sekolah dasar merupakan lembaga pendidikan formal yang pertama harus ditempuh oleh siswa sebelum melanjutkan ke jenjang pendidikan berikutnya. Menurut Piagiet dalam Slavin (2009:45) "karakteristik siswa SD cenderung berpikir operasi konkrit”, dan pada masa usia anak-anak cenderung berinteraksi dengan bermain (Slavin, 2009:93). Pembelajaran pada siswa sekolah dasar guru harus mampu melaksanakan kegiatan pembelajaran kepada hal yang cenderung menghadapkan 
sesuatu yang konkrit dan berorientasi bermain, media pembelajaran merupakan sebagai pengganti penyampai informasi apabila guru belum bisa menghadapkan sesuatu yang nyata.

Permainan ular tangga merupakan permainan tradisional yang biasa dimainkan oleh anak-anak, tidak ada sumber yang jelas sejak kapan permainan ular tangga ditemukan. Konsep permainan ular tangga yaitu permainan dimainkan 2 anak atau lebih dengan melempar dadu, yang terdiri dari beberapa kotak yang didalamnya ada gambar, dalam permainan ada gambar ular dan tangga, apabila dalam permainan mendapatkan tangga berarti naik sesuai dengan tangga tersebut, dan apabila mendapatkan ular maka dalam permainan tersebut peserta harus turun sesuai jalan ular tersebut. peserta dinyatakan menang apabila peserta nyampai pada finis yang pertama.

Media pembelajaran permainan ular tangga merupakan media pembelajaran yang dikembangkan berdasarkan permainan tradisonal permainan ular tangga disesuaikan dengan karakteristik siswa dengan tujuan untuk mencapai tujuan pembelajaran sebagai pengantar informasi bagi siswa. Kelebihan media pembelajaran permainan ular tangga yaitu (1) siswa belajar sambil bermain, (2) siswa tidak belajar sendiri, melainkan harus berkelompok, (3) memudahkan siswa belajar karena dibantu dengan gambar yang ada dalam permainan ular tangga, dan (4) tidak memerlukan biaya mahal dalam membuat media pembelajaran permainan ular tangga.

Mengingat media pembelajaran permainan ular tangga memiliki kelebihan yang dipaparkan diatas. Diharapkan penelitian ini bermanfaat untuk menumbuhkan motivasi belajar dan hasil belajar siswa, selain bermanfaat bagi siswa, penelitian ini mampu meningkatkan kualitas guru sekolah dasar dalam kegiatan belajar mengajar dan meningkatkan profesionalisme dosen dalam melaksanakan penelitian dan membantu menyelesaikan permasalahan pendidikan di sekolah dasar.

\section{METODE}

Penelitian ini merupakan penelitian pengembangan, menurut Sugiono (2012:407) penelitian pengembangan merupakan penelitian yang digunakan untuk menghasilkan produk dan menguji efektifitas produk tersebut, pengembangan dalam penelitian ini adalah media pembelajaran permainan ular tangga bidang studi ilmu pengetahuan sosial (IPS) untuk kelas III di sekolah dasar. Model pengembangan media pembelajaran dalam penelitian mengdopsi model 4D yang dikemukakan oleh Thiagarajan dkk., model pengembangan penelitian disajikan pada gambar 1.

Uji coba penelitian diterapkan media pembelajaran permainan ular tangga sebanyak dua kali, subjek penelitian siswa kelas III SDI Yapita Surabaya sebanyak 25 siwa, penelitian ini dilaksanakan pada tahun ajaran 2014-2015 semester 2 pada materi pokok jenis-jenis pekerjaan, teknik pengumpulan data untuk mengetahui motivasi belajar siswa dengan metode observasi dan pemberian angket. Sedangkan untuk mengetahui hasil belajar siswa teknik pengumpulan data dengan melakukan tes, tes hasil berbentuk pilihan ganda berjumlah 20 butir soal.

Uji validitas media pembelajaran menggunakan validitas ahli (expert Jugment), validitas media pembelajaran permainan ular tangga dilakukan oleh dua orang ahli pendidikan, instrumen lembar validasi media permainan ular tangga menggunakan skala likert dengan kriteria (1) sangat tidak baik, (2) tidak baik, (3) 
baik, dan (4) sangat baik. Teknik analisis data uji vaiditas rumus dari Ridwan dan Sunarto (2009:38) sebagai berikut:

$$
\chi=\frac{\sum \chi_{1}+\sum \chi_{2}}{n}
$$

Keterangan:

$\mathrm{X}=$ Kriteria penilaian media pembelajaran permainan ular tangga

$\Sigma \chi_{1}=$ Total skor penilaian validator 1

$\Sigma x_{2}=$ Total skor penilaian validator 2

$\mathrm{n}=$ Jumlah validator

Sedangkan uji reliabilitas media pembelajaran permainan ular tangga menggunakan uji reliabilitas teknik ulang, uji reliabilitas teknik ulang instrumen diujicobakan kepada sekelompok responden hasilnya dicatat (Arikunto, 2010:222). Uji coba media pembelajaran dilaksanakan dua kali. Uji coba pertama dilaksanakan untuk mengetahui reliabilitas media pembelajaran permainan ular tangga di ujicobakan kepada 10 siswa, yaitu mewakili 3 siswa yang memiliki kemampuan baik, 3 siswa memiliki kemampuan sedang, dan 4 siswa yang memiliki kemampuan lambat. Teknik analisis data untuk menghitung reliabilitas Ridwan dan Sunarto (2009:38) sebagai berikut:

$$
\chi=\frac{\sum \chi_{i}+\sum \chi_{2}+\sum \chi_{3}}{n}
$$

Keterangan:

$\mathrm{X}=$ Total skor tanggapan siswa terhadap media permaian ular tangga

$\Sigma \chi_{1}=$ Total skor siswa kemampuan baik $\Sigma \chi_{2}=$ Total skor siswa kemampuan sedang

$\Sigma \chi_{3}=$ Total skor siswa kemampuan sedang

$\mathrm{n} \quad=$ jumlah siswa

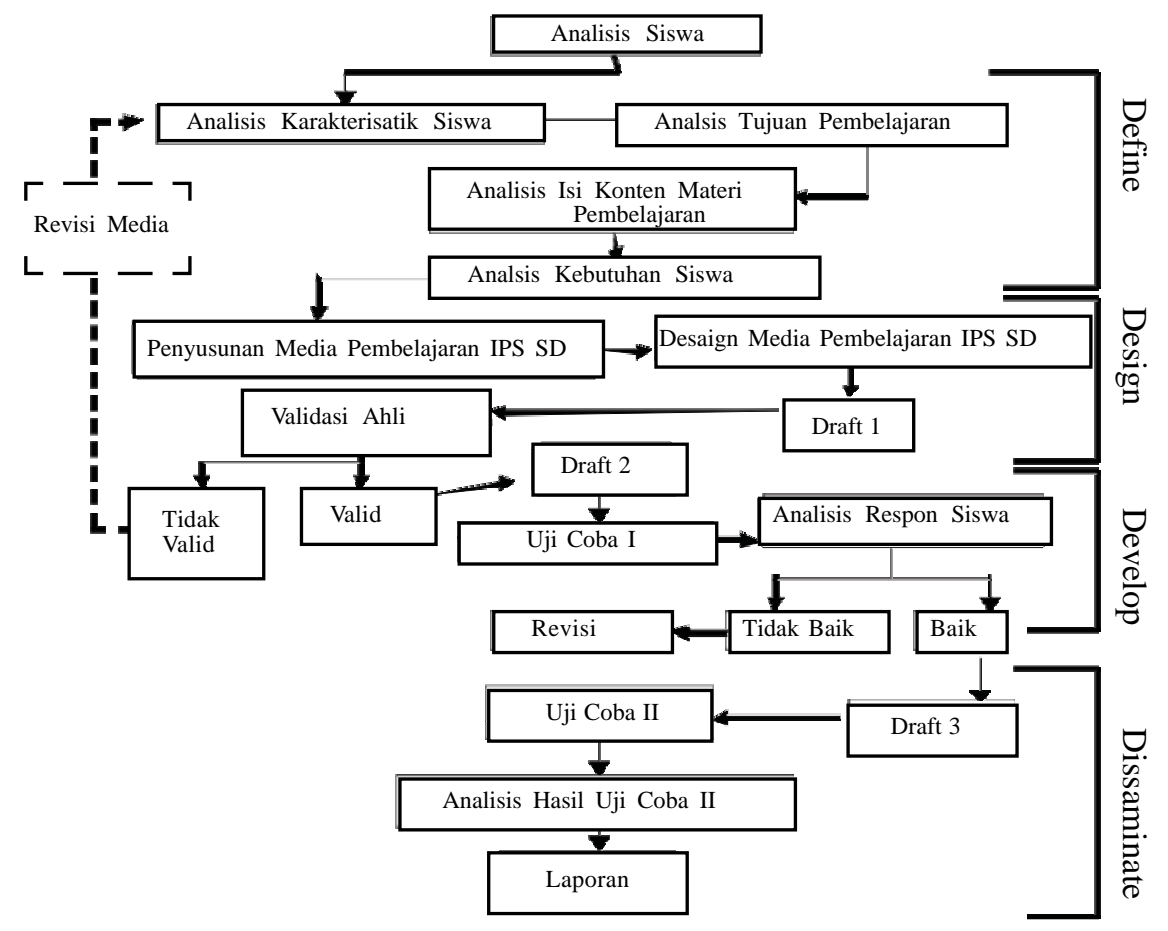

\section{Gambar 1. Desain Pengembangan Media Pembelajaran Permainan Ular Tangga diadobsi Thiagarajan, dkk. (1974)}

Uji validitas instrumen motivasi belajar tentang motivasi belajar siswa diperoleh menggunakan uji validitas konstruk. Data melalui penyekoran hasil observasi aktivitas 
siswa selama proses pembelajaran diterapkan media pembelajaran permainan ular tangga. Untuk menganalisis hasil pengamatan aktivitas siswa digunakan analisis presentase (\%), yakni banyaknya frekuensi tiap aktivitas dibagi dengan seluruh aktivitas dikali 100\%. Presentase Aktivitas siswa $=\frac{A}{B} \times 100 \%$ Keterangan :

A = Banyaknya frekuensi tiap aktivitas siswa muncul

B = Jumlah seluruh aktifitas siswa

Kriteria penilaian motivasi belajar mengacu pada methode of granding in summative evaluation dari Bloom, Madaus \& Hastings (dalam Tahmrin, 2007) yaitu:

$$
\begin{aligned}
& 90 \% \leq \mathrm{K}=\text { sangat tinggi } \\
& 80 \% \leq \mathrm{K}<90 \%=\text { tinggi } \\
& 70 \% \leq \mathrm{K}<80 \%=\text { sedang } \\
& 60 \% \leq \mathrm{K}<70 \%=\text { rendah }
\end{aligned}
$$

Uji validitas tes hasil belajar menggunakan uji validitas isi, dengan membandingkan isi instrumen dengan materi yang diajarkan (Sugiono, 2012:182). Data hasil belajar diperoleh melalui pemberian tes pilihan ganda berisi 20 butir soal, teknik analisis data Ketuntasan belajar siswa secara individual dapat dihitung dengan persamaan sebagai berikut:

$$
\mathrm{K}=\underline{\tau} \mathrm{X} 100 \%
$$

$$
\tau_{1}
$$

Keterangan:

$\mathrm{K}$ = Persen ketuntasan belajar secara klasikal

$\mathrm{T}=$ Jumlah siswa yang tuntas belajar $\tau_{1}=$ Jumlah seluruh siswa

\section{HASIL DAN PEMBAHASAN}

Berikut ini akan diuraikan secara rinci hasil pengembangan dan implementasi media pembelajaran permainan ular tangga.

\section{Validitas Konstruk}

Validasi media pembelajaran permainan ular tangga dilakukan oleh 2 ahli pendidikan, nama validator disajikan pada tabel 1.

Tabel 1. Nama Validator

\begin{tabular}{lll}
\hline \multicolumn{1}{c}{ Nama } & \multicolumn{1}{c}{ Bidang Keahlian } & \multicolumn{1}{c}{ Lembaga Asal } \\
\hline Dr. Nur Efendi, M.Pd. & Pendidikan & Muhammadiyah Sidoarjo \\
Hendri Pandu Paksi, M.Pd. & Pendidikan Dasar & Universitas Negeri Surabaya \\
\hline
\end{tabular}

Tabel 2. Hasil Validasi Media Pembelajaran permainan Ular Tangga

\begin{tabular}{lcc}
\hline \multirow{1}{*}{\multicolumn{1}{c}{ Aspek Penilaian }} & \multicolumn{2}{c}{ Skor } \\
\cline { 2 - 3 } & \multicolumn{2}{c}{ Kriteria Penilaian } \\
\cline { 2 - 3 } & Validator & Validator \\
\hline Penampilan media pembelajaran & Baik & Baik \\
Kejelasan tulisan media pembelajaran yang disampaikan & Baik & Sangat Baik \\
Kejelasan gambar pada media yang disampaikan & Sangat Baik & Sangat Baik \\
Kesesuaian media pembelajaran dengan tujuan pembelajaran & Sangat Baik & Sangat Baik \\
Kesesuaian media dengan isi konten materi pembelajaran & Sangat Baik & Sangat Baik \\
Petunjuk penggunaan media pembelajaran & Sangat Baik & Baik \\
Kesesuaian media dengan karakteristik siswa sekolah dasar & Sangat Baik & Sangat Baik \\
Kesesuaian media dengan konsep permaian ular tangga & Sangat Baik & Sangat Baik \\
\hline Rata-rata kriteria penilaian kedua validator & Sangat Baik & Sangat Baik \\
\hline
\end{tabular}

Sumber: Data yang Sudah diolah

Keterangan Kriteria penilaian

Skor $0-1=$ Sangat tidak baik (Media tidak dapat digunakan)

Skor 1-2 = Tidak baik (Media memerlukan konsultasi dan revisi)
Skor 2-3 = Baik (Media dapat digunakan sedikit revisi)

Skor 3-4 = Sangat baik (Media dapat digunakan) 
Hasil validasi media pembelajaran permainan ular tangga disajikan pada tabel 2. Berdasarkan tabel 2 tersebut Hasil uji validitas kedua validator memberikan kriteria penilaian sangat baik, Tabel tersebut menunjukkan bahwa media pembelajaran permainan ular tangga yang dikembangkan layak digunakan (valid).

Pengembangan media pembelajaran permainan ular tangga dalam penelitian ini mengacu pada prinsip-prinsip evaluasi media pembelajaran Sadiman, dkk. (1984:92) mengemukakan yaitu (1) media pengajaran harus sesuai dengan tujuan pembelajaran, (2) kosakata (3) kesesuaian dengan isi materi, (4) kesesuaian dengan berbagai jenis siswa (karakteristik siswa), dan (4) Kualitas gambar atau visual. Prinsip-prinsip penilaian media pembelajaran tersebut digunakan agar media yang dikembangkan sesuai dengan tujuan yang diharapkan.

Sedangkan menurut Asnawir dan Usman (2002:19) syarat umum yang harus dipenuhi dalam penggunaan media yaitu (1) media pembelajaran harus sesuai dengan materi pembelajaran yang diterapkan, (2) media tersebut harus bisa dilihat dan di dengar, (3) media pengajaran harus dapat merespon siswa belajar, dan
(4) media pengajaran harus sesuai dengan kondisi individu siswa.

Berdasarkan kedua pendapat ahli tersebut, bahwa pengembangan media pembelajaran permainan ular tangga dalam pembelajaran IPS pada penelitian ini sudah sesuai dengan kriteria pakar media pendidikan, sehingga media pembelajaran permainan ular tangga dalam penelitian layak digunakan dalam pembelajaran IPS di sekolah dasar.

\section{Reliabilitas Teknik Ulang}

Uji reliabilitas dilakukan melalui uji realibilitas eksternal teknik ulang, uji realibilitas eksternal teknik ulang dilakukan mengujicobakan instrumen atau produk yang dikembangkan beberapa kali dan kemudian hasilnya dicatat (Arikunto, 2010:222), uji reliabilitas media pembelajaran permaianan ular tangga dilaksananakan pada uji coba I. Uji coba I diterapkan pada 10 siswa, 3 siswa kemampuan cepat, 3 siswa kemampuan sedang, dan 4 siswa dengan kemampuan lambat. Uji realibilitas dilaksananakan melalui pemberian angket pada siswa terhadap penggunaan media pembelajaran permainan ular tangga. Hasil uji realibilitas disajikan pada tabel 3 berikut:

Tabel 3. Uji Realibilitas Media Pembelajaran Permaian Ular Tangga

\begin{tabular}{lcc}
\hline \multicolumn{1}{c}{ Keterangan } & \multicolumn{2}{c}{ Kriteria Jawaban Siswa } \\
\cline { 2 - 3 } & Frekuensi & \% \\
\hline Apakah gambar pada permaianan ular tangga jelas & 10 & $100 \%$ \\
$\begin{array}{l}\text { Apakah tulisan pada permaianan ular tangga mudah kamu } \\
\text { mengerti }\end{array}$ & 10 & $100 \%$ \\
$\begin{array}{l}\text { Apakah media ular tangga yang diberikan guru mudah } \\
\text { kamu gunakan }\end{array}$ & 10 & $100 \%$ \\
$\begin{array}{l}\text { Apakah kamu mengerti isi yang di sampaikan pada } \\
\text { permaianan ular tangga yang diberikan guru }\end{array}$ & \multicolumn{2}{c}{$\mathbf{1 0 0 \%}$} \\
\hline Rata-rata (\%)
\end{tabular}

Sumber: Data sudah di olah

Hasil uji reliabilias media pembelajaran permaianan ular tangga berdasarkan tabel 3 rata-rata siswa memberikan respon $100 \%$ menyatakan tidak ada kendala diterapkan media pembelajaran permaianan ular tangga, hal tersebut menunjukkan media pembelajaran permaian ular tangga bisa 
digunakan oleh semua siswa dengan karakteristik yang berbeda, baik siswa dengan kemampuan cepat, sedang maupun lambat.

Hasil observasi uji coba I penerapan media pembelajaran permainan ular tangga siswa tidak mengalami kendala atau hambatan. Hal tersebut menunjukan bahwa media pembelajaran permainan ular tangga menunjukkan ke ajegan.

\section{Hasil Pengembangan Media Pembelajaran Permainan Ular Tangga (Pengembangan Produk).}

Media pembelajaran permainan ular tangga yang dikembangkan dalam penelitian adalah hasil permainan ular tangga yang biasa digunakan oleh anak-anak. Hasil penelitian pengembangan media pembelajaran permainan ular tangga yaitu terdiri dari 36 kolom (kotak), setiap kotak berisi informasi isi konten materi yang diberikan dalam pembelajaran, dan ada beberapa kolom (kotak) yang berisikan gambar beserta isi konten materi pembelajaran ilmu pengetahuan sosial (IPS) materi ajar jenis-jenis pekerjaan pada kelas III sekolah dasar. Hasil pengembangan media pembelajaran permainan ular tangga disajikan pada gambar 2 .

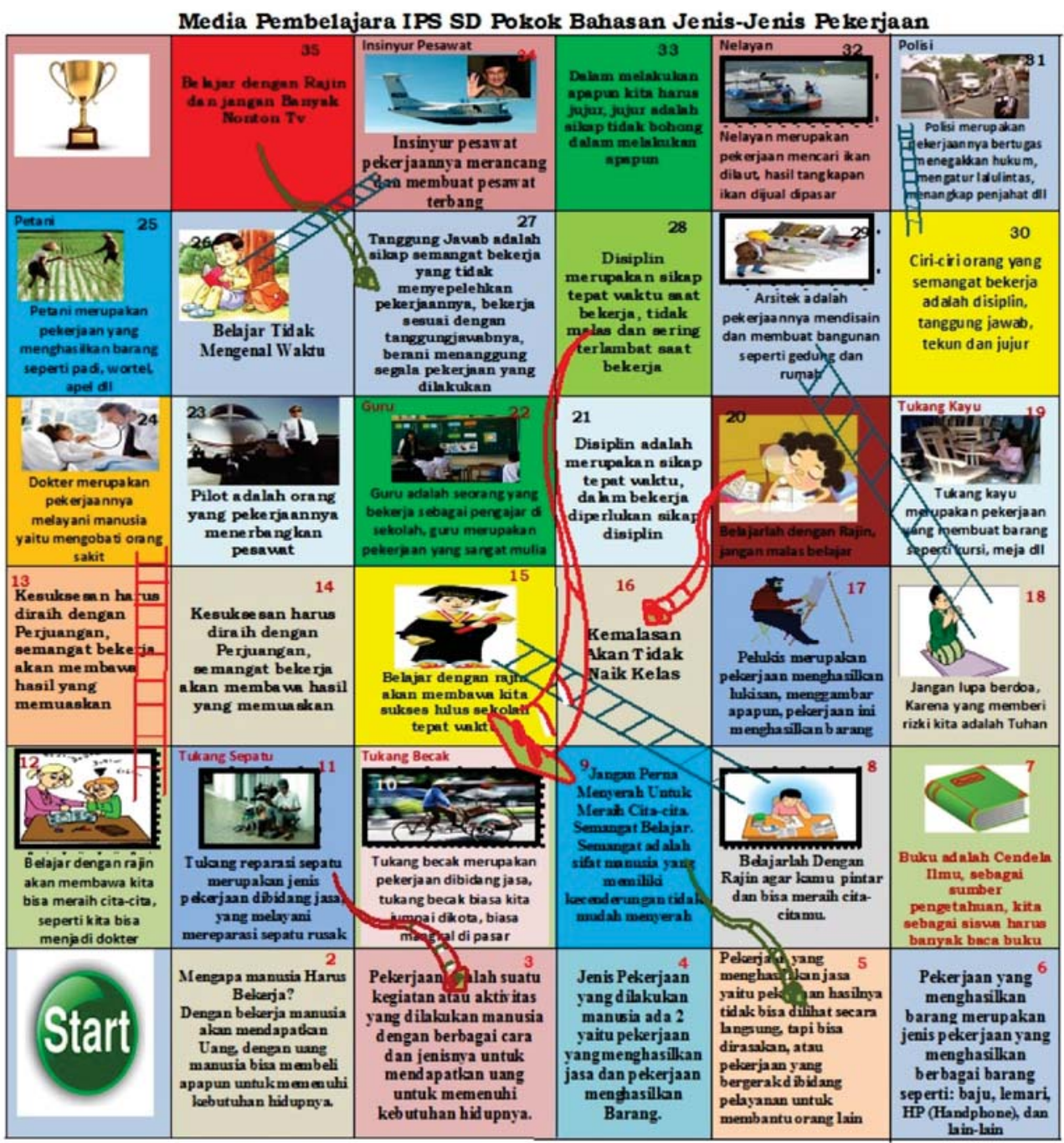

Gambar 2. Hasil Pengembangan Media Pembelajaran Permainan Ular Tangga dalam Pembelajaran IPS di Sekolah Dasar 
Konsep penggunaan media pembelajaran permainan ular tangga dimodifikasi oleh peneliti, penggunaan media pembelajaran permainan ular tangga yang dikembangkan yaitu (1) media ini dimainkan oleh 4-5 siswa, (2) permainan di mulai dari start, (3) setiap siswa wajib melempar dadu sebelum melakukan langkah permainan, (4) setiap siswa melangkah sesuai dengan angka yang didapatkan pada dadu yang dilempar, (5) setiap siswa yang mendapatkan langkah sesuai mata dadu, siswa kotak (kolom) yang dilewati, sehingga siswa memperoleh informasi mengenai konten materi pembelajaran dan tujuan pembelajaran tercapai.

Desain pengembangan dalam penelitian mengacu pada desain 4D pengembangan pembelajaran Thiagarajan, dkk. (1974), dimana alur pengembangan media pembelajaran permainan ular tangga tersebut langkah yang ditempuh yaitu define, design, develop, dan dissaminate. Alur tersebut mencakup analisis karakteristik siswa, analisis tujuan pembelajaran, analisis isi konten materi pembelajaran, analisis kebutuhan siswa, uji coba media pembelajaran, dan pelaporan.

Pendapat Thiagarajan, dkk. tersebut sesuai dengan pendapat Sadiman, dkk. (1984:100) bahwa urutan pengembangan media yaitu (1) menganalisis dan kebutuhan karakter siswa (2) merumuskan tujuan operasional, (3) merumuskan butir-butir materi secara terperinci yang medukung tercapainya tujuan, mengembangkan alat ukur keberhasilan,(4) menuliskan naskah media, dan (5) mengadakan tes dan revisi.

Tahap pengembangan media pembelajaran permainan ular tangga dalam penelitian, sudah sesuai dengan kaidah langkah-langkah atau alur tahap pengembangan media berdasarkan kaidah langkah-langkah atau alur tahap pengembangan media berdasarkan pendapat ahli, tahap pengembangan media tersebut disajikan pada gambar 1 .

Tahap pengembangan media pembelajaran permainan ular tangga dalam penelitian yaitu menganalilis karakter siswa kelas III di SD Yapita Surabaya, analisis tujuan pembelajaran sesuai dengan standar isi pada kurikulum yang di implementasikan dalam pembelajaran dan dari penjabaran kompentensi dasar melalui indikator pembelajaran, analisis konten materi dalam pembelajaran IPS kelas III di sekolah dasar.

Analisis kebutuhan siswa sesuai dengan tujuan dari pengembangn media pembelajaran yaitu meningkatkan motivasi belajar siswa dan hasil belajar siswa pada pembelajaran IPS kelas III di sekolah dasar.

\section{Motivasi Belajar}

Hasil motivasi belajar siswa diterapkan media pembelajaran permaianan ular tangga disajikan pada tabel 4 dan tabel 5 .

Tabel 4. Motivasi Belajar Siswa Berdasarkan Observasi atas Beberapa

\begin{tabular}{|c|c|c|c|c|c|}
\hline \multirow{2}{*}{$\begin{array}{l}\text { Aspek } \\
\text { Motivasi } \\
\text { Belajar }\end{array}$} & \multirow[t]{2}{*}{ Deskripsi } & \multicolumn{2}{|c|}{$\begin{array}{c}\text { Sebelum } \\
\text { diterapkan Media } \\
\text { Ular Tangga } \\
\end{array}$} & \multicolumn{2}{|c|}{$\begin{array}{c}\text { Diterapkan } \\
\text { diterapkan Media } \\
\text { Ular Tangga } \\
\end{array}$} \\
\hline & & Frekuensi & $\%$ & Frekuensi & $\%$ \\
\hline \multirow[t]{2}{*}{$\begin{array}{l}\text { Aktif dalam } \\
\text { pembelajaran }\end{array}$} & $\begin{array}{l}\text { - Siswa aktif mengerjakan tugas } \\
\text { yang diberikan guru }\end{array}$ & 10 & $40 \%$ & 25 & $100 \%$ \\
\hline & $\begin{array}{l}\text { - Siswa mengikuti kegiatan } \\
\text { pembelajaran sesuai dengan } \\
\text { instruksikan guru }\end{array}$ & 10 & $40 \%$ & 23 & $92 \%$ \\
\hline
\end{tabular}




\begin{tabular}{|c|c|c|c|c|c|}
\hline \multirow{2}{*}{$\begin{array}{l}\text { Aspek } \\
\text { Motivasi } \\
\text { Belajar }\end{array}$} & \multirow[t]{2}{*}{ Deskripsi } & \multicolumn{2}{|c|}{$\begin{array}{c}\text { Sebelum } \\
\text { diterapkan Media } \\
\text { Ular Tangga } \\
\end{array}$} & \multicolumn{2}{|c|}{$\begin{array}{c}\text { Diterapkan } \\
\text { diterapkan Media } \\
\text { Ular Tangga } \\
\end{array}$} \\
\hline & & Frekuensi & $\%$ & Frekuensi & $\%$ \\
\hline & $\begin{array}{l}\text { - Siswa bekerja sama dengan } \\
\text { kelompok dalam kegiatan } \\
\text { pembelajaran }\end{array}$ & 6 & $24 \%$ & 25 & $100 \%$ \\
\hline \multirow[t]{7}{*}{$\begin{array}{l}\text { Semangat } \\
\text { dalam } \\
\text { pembelajaran }\end{array}$} & $\begin{array}{l}\text { - Siswa tidak bicara sendiri } \\
\text { ketika mengikuti pembelajaran } \\
\text { IPS (berbicara diluar konten }\end{array}$ & 6 & $24 \%$ & 22 & $88 \%$ \\
\hline & $\begin{array}{l}\text { materi pembelajaran dan } \\
\text { permainan ular tangga) }\end{array}$ & 6 & $24 \%$ & 23 & $92 \%$ \\
\hline & $\begin{array}{l}\text { - Siswa tidak merasa bosan } \\
\text { dalam mengikuti pembelajaran } \\
\text { IPS }\end{array}$ & 5 & $20 \%$ & 22 & $88 \%$ \\
\hline & $\begin{array}{ll}\text { - } & \text { Siswa antusias mengikuti } \\
& \text { pembelajaran IPS }\end{array}$ & 8 & $32 \%$ & 25 & $100 \%$ \\
\hline & pembelajaran IPS & 7 & $28 \%$ & 24 & $96 \%$ \\
\hline & 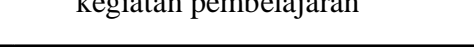 & 6 & $24 \%$ & 25 & $100 \%$ \\
\hline & Rata-Rata (\%) & \multicolumn{2}{|c|}{$28,4 \%$} & \multicolumn{2}{|c|}{$95,1 \%$} \\
\hline
\end{tabular}

Sumber: Data yang Sudah di Olah

Berdasarkan tabel 4 motivasi belajar siswa pada aspek keaktifan dan semangat belajar menunjukkan bahwa sebelum diterapkan media pembelajaran permainan ular tangga pada aspek tersebut sebesar 28,4\% siswa yang memiliki motivasi belajar dalam pembelajaran IPS, hal tersebut menunjukkan motivasi belajar siswa dalam pembelajaran IPS sangat rendah. Sedangkan pada saat diterapkan media pembelajaran permainan ular tangga motivasi belajar siswa pada aspek keaktifan dan semangat belajar sebesar 95,1\% siswa yang memiliki motivasi belajar IPS , setelah diterapkan media permbelajaran permainan ular tangga motivasi belajar siswa mengalami peningkatan $66,7 \%$. Hal tersebut motivasi belajar siswa pada aspek keaktifan dan semangat belajar dalam pembelajaran IPS sangat tinggi.

Sedangkan motivasi belajar siswa pada aspek ketertarikan dalam pembelajaran IPS disajikan pada tabel 5.

Tabel 5. Motivasi Belajar Siswa Berdasarkan Aspek Ketertarikan

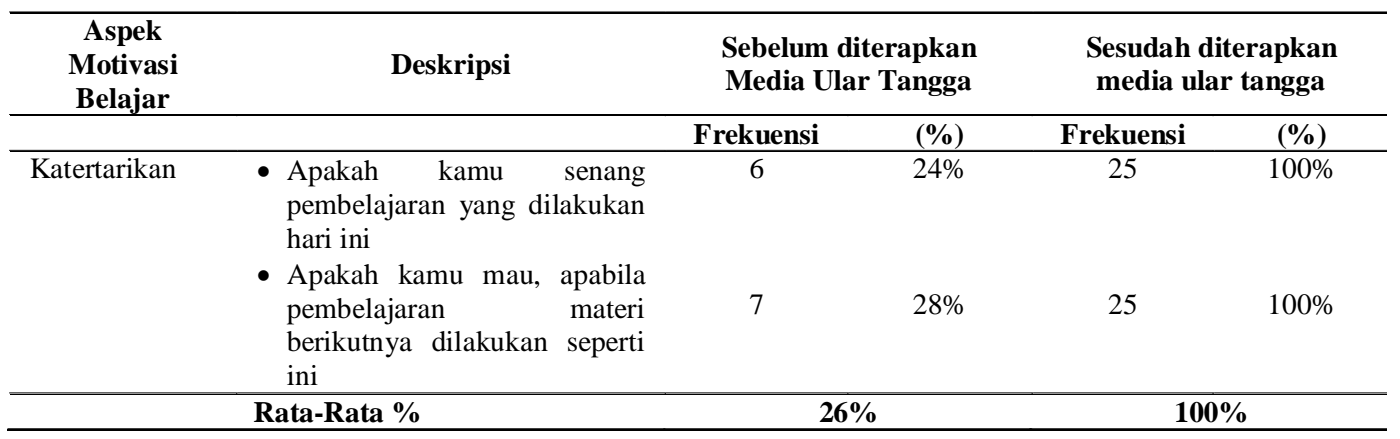

Sumber: Data yang Sudah di Olah

Berdasarkan tabel 5 motivasi belajar

26\% siswa yang memiliki motivasi belajar dalam pembelajaran IPS. Namun, setelah siswa pada aspek ketertarikan menunjukkan diterapkan media pembelajaran permainan 
ular tangga motivasi belajar siswa pada aspek ketertarikan menunjukkan rata-rata 100\% siswa memiliki motivasi belajar, hal tersebut terjadi peningkatan 74\% peningkatan motivasi belajar siswa diterapkan media pembelajaran permainan ular tangga dalam pembelajaran IPS pada aspek ketertarikan sangat tinggi.

Menurut Sardiman (2011:83) ciri-ciri orang yang memiliki motivasi belajar adalah tekun mengerjakan tugas, menunjukkan minat atau ketertarikan terhadap hal yang dipelajari, sedangkan menurut Uno (2009:23) indikator motivasi belajar antara lain adanya hal menarik dalam belajar, adanya lingkungan belajar yang kondusif. Jelaslah aspek yang diungkapkan dalam penelitian ini yaitu aspek keaktifan siswa dalam kegiatan pembelajaran, semangat siswa dalam mengikuti pembelajaran dan minat atau ketertarikan siswa dalam mengikuti pembelajaran.

Menurut Sadiman, dkk. (1984:75) permainan (games) adalah setiap kontes para pemain yang berinteraksi satu sama lain dengan mengikuti aturan-aturan untuk mencapai tujuan-tujuan tertentu pula. Belajar sambil bermain dapat menumbuhkan motivasi belajar siswa, Slavin (2009) menyatakan "pada prinsipnya karakteristik anak-anak cenderung suka bermain”, sejalan dengan pendapat Sadiman, dkk. (1984:78) kelebihan media pembelajaran permainan adalah adanya partisipasi aktif dari siswa untuk belajar, adanya interaksi antar siswa sehingga adanya kerjasama kelompok dalam siswa, hal tersebut sesuai dengan aspek motivasi belajar siswa dan konsep media pembelajaran permainan ular tangga yang dikembangkan dalam penelitian.

Penggunaan media pembelajaran dalam kegiatan pembelajaran lebih memudahkan siswa dalam memperoleh pemahaman dan memotivasi siswa untuk belajar, sejalan dengan pendapat Sadiman, dkk. (2008:17) menyatakan media pembelajaran berguna menimbulkan kegairahan belajar, sedangkan Asnawi dan Usman (2002:14) menyatakan media pembelajaran dapat membangkitkan motivasi dan merangsang siswa untuk belajar. Berdasarkan pendapat ahli tersebut bahwa media pembelajaran dapat menumbuhkan motivasi belajar siswa dalam proses pembelajaran.

\section{Hasil Belajar}

Hasil belajar siswa dapat dilihat pada tabel 6. Pada tabel 6 tersebut menunjukkan bahwa hasil belajar siswa dalam pembelajaran IPS sebelum diterapkan media pembelajaran permainan ular tangga menunjukkan bahwa 55\% siswa yang memiliki nilai diatas KKM (Kriteria Ketuntasan Minimum), sedangkan setelah diterapkan media pembelajaran permainan ular tangga $100 \%$ siswa memiliki nilai diatas KKM (Kriteria Ketuntasan Minimum), hal tersebut menunjukkan hasil belajar siswa terjadi peningkatan $45 \%$.

Penggunaan media pembelajaran dalam kegiatan pembelajaran lebih memudahkan siswa dalam memperoleh pemahaman dan memotivasi siswa untuk belajar, sejalan dengan pendapat Sadiman, dkk. (2008:17) media pembelajaran berguna memperjelas penyajian pesan agar tidak terlalu verbalis dan menimbulkan kegairahan belajar.

Tabel 6 Hasil belajar

\begin{tabular}{|c|c|c|}
\hline \multirow{7}{*}{ Keterangan } & $\begin{array}{c}\text { Sebelum } \\
\text { diterapkan } \\
\text { Media ular } \\
\text { Tangga }\end{array}$ & $\begin{array}{c}\text { Setelah } \\
\text { diterapkan } \\
\text { media ular } \\
\text { tangga }\end{array}$ \\
\cline { 2 - 3 } & $\begin{array}{c}\text { Nilai }< \\
\text { KKM }\end{array}$ & $\begin{array}{c}\text { Nilai< } \\
\text { KKM }\end{array}$ \\
\cline { 2 - 3 } & $\%$ & $\%$ \\
\hline $\begin{array}{c}\text { Hasil Belajar } \\
\text { Pembelajaran } \\
\text { IPS }\end{array}$ & $55 \%$ & $100 \%$ \\
\hline
\end{tabular}

Sumber: Data yang sudah di olah 
Sedangkan Asnawir dan Usman (2002:14) menyatakan bahwa media pembelajaran dapat menanamkan konsep dasar yang benar dan konkrit, dan realistis. Penggunaan media seperti gambar, film, model grafik, dan lainnya. Pendapat tersebut menyatakan bahwa media pembelajaran dapat memberikan pemahaman pada konsep-konsep yang abstrak, dengan gambar diharapkan siswa tidak berpikir secara abstrak sehingga siswa mampu berpikir sesuai dengan konsep yang diharapkan.

Media pembelajaran permainan ular tangga dalam penelitian terdiri atas gambargambar yang berhubungan dengan isi konten materi pembelajaran IPS kelas III, tidak hanya gambar, namun juga diberikan keterangan gambar yang berhubungan isi konten materi yang di ajarkan. Menurut Dale dalam USAID (2013) menyatakan bahwa pembelajaran dengan menggunakan bantuan visual (gambar) lebih baik ditangkap siswa dari pada pembelajaran yang bersifat verbal dan simbol.

Jelaslah bahwa pengembangan media pembelajaran permainan ular tangga dalam penelitian ini, memperhatikan kaidah pengembangan media pembelajaran diantaranya adanya gambar, penyampaian pesan melalui tulisan yang jelas, penyesuaian karakteristik siswa, dan tujuan pembelajaran bedasarkan isi materi. Dengan demikian, media pembelajaran permainan ular tangga yang dikembangkan mampu meningkatkan hasil belajar siswa.

\section{SIMPULAN}

Berdasarkan uraian dan temuan yang diperolah dalam penelitian ini dapat dikemukakan kesimpulan sebagai berikut: Pengembangan media pembelajaran permainan ular tangga dalam pembelajaran IPS dinyatakan valid oleh validator. Hasil implementasi media pembelajaran permainan ular tangga dalam pembelajaran IPS bahwa motivasi belajar siswa meningkat dengan kriteria motivasi belajar sangat tinggi. Hasi belajar siswa dalam pembelajaran IPS meningkat dengan diterapkan media pembelajaran permainan ular tangga, Hasil belajar siswa meningkat dan Hasil belajar siswa mencapai nilai di atas KKM (Ketuntasan Kriteria Minimum).

Berdasarkan hasil pembahasan dapat dikemukakan saran bahwa Sekolah dasar sebagai tempat belajar formal bagi anakanak, dalam kegiatan proses belajar mengajar dimana anak-anak sering mengalami kebosanan, sehingga guru diharapkan mampu mengelola kelas dengan baik. Dalam mengatasi setiap permasalahan pembelajaran, salah satu alternatif menyelesaikan pemasalahan tersebut yaitu melalui media pembelajaran permainan ular tangga

\section{DAFTAR PUSTAKA}

Alma, Buchori dkk. 2010. Pembelajaran Studi Sosial. Bandung. Alfabeta

Arikunto. 2010. Prosedur Penelitian: Suatu Pendekatan Praktik. Jakarta: Rineka Cipta.

Arsyad, Azhar. 2011. Media Pembelajaran. Jakarta: Rajawali Pers.

Asnawir, H. \& Usman M., Basyiruddin 2002. Media Pembelajaran. Jakarta: Ciputat Pers.

Depdiknas. 2003. Undang-undang Sistem Pendidikan Nasional No. 20 Tahun 2003. Jakarta: Depdiknas.

Depdiknas. 2005. Undang-undang Guru dan Dosen No. 14 Tahun 2005. Jakarta: Depdiknas.

Kemendikbud. 2013. Peraturan Menteri Pendidikan dan Kebudayaan No. 67 Tahun 2013. Jakarta: Kemendikbud. Ridwan \& Sunarto, H. 2009. Pengantar Statistika: Untuk Penelitian 
Pendidikan, Sosial, Ekonomi, Komunikasi dan Bisnis. Cetakan ke 4 April 2011. Bandung: Alfabeta.

Sadiman S., Arief., Raharjo R., \& Haryanto, Anung . 1984. Media Pendidikan. Pengertian, Pengembangan dan Pemanfaatannya. Cetakan 2007. Jakarta: Raja Gra findo Persada.

Sardiman. 2011. Interaksi dan Motivasi Belajar Mengajar.Jakarta: Raja Grafindo Persada.

Sapriya., Istianti, Tuti., \& Zulkifli, Effendi. 2007. Pengembangan Pendidikan IPS SD. Bahan Belajar Mandiri. Bandung: Fakultas Ilmu Pendidikan UPI. UPI Press.

Slavin, E., Robert. 2009. Psikologi Pendidikan, Teori dan Praktik. Edisi Kesembilan Jilid I.Terjemah-an Murianto Samosir. New Jersey: Person Education, Inc.

Sugiyono. 2012. Metode Penelitian Pendidikan: Pendekatan Kuantitatif, Kualitatif dan $R$ \& $D$. Bandung: Alfabeta.

Sumaatmadja, Nursid. 2007. Konsep Dasar IPS. Modul 1-2. Jakarta: Universitas Terbuka.

Thiagarajan., Semmel \& Semmel. 1974. Intructional Development for Training Teachers of Exeptional Children A Sourcebook. Blomington Indiana: Indiana University.

Tahmrin, S. 2007. Model Pembelajaran Resik Sebagai Strategi Mengubah Paradigma Pembelajaran Matematika di SMP yang Teachers Oriented Menjadi Student Oriented. Penelitian Hibah Bersaing Dosen S2 Pendidikan Matematika PPs UNM Makasar.

Uno, Hamza B. 2009. Teori Motivasi dan Pengukurannya. Jakarta: Bumi Aksara.

USAID. 2013. Praktik Yang Baik dalam Pembelajaran. di Sekolah dasar dan MI. Jakarta: USAID.
Winataputra, dkk., 2007. Materi dan Pembelajaran IPS SD. Buku Materi Pokok. Jakarta: Universitas Terbuka. Winingsih, H. Lucia, dkk. 2007. Peningkatan Mutu, Relevansi dan Daya Saing Pendidikan. Jakarta: Pusat Dokumentasi dan Informasi Ilmiah-Lembaga Ilmu Pengetahuan Indonesia PDII-LIPI, diakses 2 Desember 2014 on-line www. Pdii.lipi.go.id/katalog/index.php/ searchkatalog/byld/257453.

Zubaidah, Siti. 2008. Pembelajaran Kontekstual Metode Inkuiri Untuk Meningkatkan Kemampuan Berpikir dan Motivasi Belajar IPA Siswa Kelas V Madrasah Ibtidaiyah Wahid Hasyim III Malang. Jurnal Ilmu Pendidikan Volume 15, Nomer I April 2008. Malang: Lembaga Pendidikan dan Pembelajaran Universitas Negeri Malang. 